Research Article

\title{
The Economic Impacts of COVID-19 on Micro and Small Enterprises: Empirical Evidences from Oromia National Regional State, Ethiopia
}

\author{
Milkessa Wakjira, Fikiru Temesgen*, Chala Hailu and Dabesa Wegari
}

Ambo University, Ambo, Ethiopia.

\begin{abstract}
This article aims to assess the economic impact of COVID-19 outbreak on these businesses to provide policy recommendations to support MSE. Primary data and secondary data were used for this study as the source of data. Three multistage sampling techniques was employ to select $372 \mathrm{MSE}$ in six district towns of Western Shewa Zone by administering personal interview. Descriptive statistics such as percentage, frequency, maximum, minimum, mean and standard deviation were used to measure the association and growth probability of MSEs. The major problems finding in the study area were facing multiple issues such as increase in cost of production, shortage of workers and reduction in sales and profit. More than $70 \%$ of participating respondents reported that they could not survive if the present trend lasts more than three months. As a temporary solution to sustain their business 169 (45.40\%) reduced the number of their employees, 73 (19.60\%) laid off their employees as the result of the pandemic crisis. The findings of study are consistent with previous studies and so that national authorities must continue taking a host of measures to provide support to ensure continuity and minimize damage in the small and micro enterprises sector. Therefore, for this study, Policymakers have to come together, and coordinate their work in the financial as well as the productive and service sectors in Ethiopia.

Received | November 25, 2020; Accepted | May 18, 2021; Published | November 23, 2021

*Correspondence | Fikiru Temesgen, Ambo University, Ambo, Ethiopia; Email: fiktems@gmail.com

Citation | Wakjira, M., F. Temesgen, C. Hailu and D. Wegari. 2022. The economic impacts of COVID-19 on micro and small enterprises: Empirical evidences from Oromia national regional state, Ethiopia. Sarhad Journal of Agriculture, 38(1): 76-80.

DOI | https://dx.doi.org/10.17582/journal.sja/2022/38.1.76.80

Keywords | COVID-19, Economic impact, SMEs, Policy recommendation
\end{abstract}

\section{Introduction}

$\mathrm{I}$ $\mathrm{n}$ developing economies, micro and small business enterprises make a significant contribution to local employment and to overall gross domestic product (GDP). An economic downturn due to COVID-19, to which Small and micro enterprises are especially vulnerable, hits developing economies at the heart. In breakable time, this poses an extra challenge. An economic downturn may well push communities already impacted by poverty and food insecurity, and with limited economic diversity and low levels of investment, over the edge. Often, in fragile and conflict-affected settings, the state has limited ability to track and contain the spread of the virus, and to treat those affected by it (IFC, 2020).

Small and micro enterprises is one of the sector given recognition in the country's industry development plan and believed that it serves as vehicles reducing poverty and unemployment at urban center and as it reinforces the economic development. As specified in Ethiopian government national plan, the industrial strategy has given outstanding focus to strengthen micro and small enterprise. This study helps to assess the knowledge and attitudes of micro and small Business Enterprises towards the Covid-19 disease. This study helps to find out the knowledge gaps 
among the people regarding the Covid-19 and the misconceptions and superstitious beliefs prevailing in the society about it (Worldometer, 2020).

Small and micro enterprises experienced a larger decline in businesses activity compared to medium and large firmsan unsurprising finding since most of the country's Small and micro enterprises halted operations due to their inability to implement preventative health measures such as provision of onsite lodging for employees, and sanitizers and hand washing equipment for customers (IFC, 2020).

The COVID-19 pandemic is badly hurting the Small and micro enterprises sector in Ethiopia, which constitutes the majority of the business and an important driver of growth. One of the important issues regarding the Small and micro enterprises in the study areas were the problem of demand supply. There is a great gap between demand and supply in order to satisfy the satisfaction of the firms. COVID-19 demoralizes all the actors of Small and micro enterprisesstarting from input supply to the final consumers. People kept their distance to provide community and to have service form Small and micro enterprises in order to kept them from COVID-19. The aim of the study was to assess the income loss due to COVID-19 at each chain of production particularly focused on the firms, consumers and mangers (ILO, 2020).

Now days, in Ethiopia, particularly in the study areas there are many challenges which hinder Small and micro enterprises to be sustainable their business during the COVID-19. Many of the important problem raised from them is there is crucial lack of information which have great impact of the business in order to handling their consumer. While the number of consumers were minimized from their consumers the looking for close and their income going to decrease accordingly. This is not the problem raised in study areas only, but it can exist all over the corner of the country.

The current studies available on the negative economic impact of the pandemic on nation's economy or individual sectors like Small and micro enterprises are based on simple assumptions. Such type of studies cannot justify for planners and policy makers in allocating the nation's scarce resources for the purpose sought. This study would fill this gap. Therefore, the aim of this study was critically attempted to critically examine the economic impact of COVID-19 on Small and micro enterprises in the Ethiopian context by employing appropriate data and techniques at local level.

The ultimate goal of this study is, therefore, to assessing the economic impact of the corona virus on the Small and micro enterprises in Ethiopia with the aimed to identify the problems of owner of the Small and micro enterprises in Ethiopia.

\section{Materials and Methods}

\section{Source of data}

Both primary and secondary data were used as the source of data. Primary data sources were traders, consumers, managers and Small and micro enterprises from three purposely selected kebeles. Secondary data were collected from the published materials and supported data were taken from the trade and market development of the study areas.

\section{Sampling techniques}

For this study multistage sampling techniqueswas employed. In the first stage, five enterprises were selected from the total of seven enterprises purposively based on the large number of enterprises engaged in it. These are manufacturing, construction, livestock, services, and traders. In the second stage, 5, 7, 5, 14 and 15 enterprises were selectedfrom each town using $10 \%$ sampling intensity from manufacturing, construction, livestock, services, and traders respectively. In the third stage, by using quota sampling $101,56,66,160$, 41, and 170 members of enterprises from Inchin, Bako, Gedo, Ginchi, Olankomi, and Ambo towns was respectively which gives a total of 372 respondents.

\section{Method of data analysis}

Descriptive statistics were used to analyze Small and micro enterprises owner/manager demographic characteristics. SPSS and STATA software were employed to process the data using percentage, frequency, maximum, minimum, mean and standard deviation were used to analyze the data take from primary and secondary data.

\section{Results and Discussion}

\section{Background characteristics of respondents under COVID-19}

As shown in Table 1, out of the total 372 respondents, 
male respondents constitute $253(65 \%)$ while that of women comprises of $137(35 \%)$ of the total respondents. The percentage of respondents age $30-40(40.05 \%)$ is more than one and half of the percentage of respondents age between $40-50$ $(22.85 \%)$. The smallest age group of the respondents $85(22.85 \%)$ fall between 40 and 50 with the mean, maximum and minimum age of 33, 45 and 22 for the whole sample population, respectively. About $227(61.08 \%)$ of the respondents were married and $88(23.70 \%)$ were separated and $57(15.50 \%)$ have never been married. Education levels were low in the case of the respondents. Overall, 97(26.08\%) of the respondents had no formal education while $56(15.05 \%)$ have attended primary/middle school up to six grade, $59(15.86 \%)$ had a secondary education, $127(34.14 \%)$ had diploma or middle level education while $33(8.87 \%)$ had first or bachelor degree.

Table 1: Description of respondents' characteristics.

\begin{tabular}{|c|c|c|c|}
\hline Variable & Characteristics & Frequency & Percentage \\
\hline \multirow[t]{2}{*}{ Gender } & Male & 253 & 65.00 \\
\hline & Female & 137 & 35.00 \\
\hline Age & $\begin{array}{l}20-30 \\
30-40 \\
40-50\end{array}$ & $\begin{array}{l}138 \\
149 \\
85\end{array}$ & $\begin{array}{l}37.10 \\
40.05 \\
22.85\end{array}$ \\
\hline \multirow[t]{5}{*}{ Education } & No formal education & 97 & 26.08 \\
\hline & Six grade and less & 56 & 15.05 \\
\hline & Seven to $12^{\text {th }}$ grade & 59 & 15.86 \\
\hline & Diploma & 127 & 34.14 \\
\hline & First Degree and above & 33 & 8.87 \\
\hline \multirow{3}{*}{$\begin{array}{l}\text { Marital } \\
\text { status }\end{array}$} & Single & 57 & 15.30 \\
\hline & Married & 227 & 61.08 \\
\hline & Separated & 88 & 23.70 \\
\hline
\end{tabular}

Source: Survey result, 2020.

Status business sector and types of business ownership, and employment size under COVID-19

The great majority of the Small and micro enterprises in which the respondents involved are legally registered 250(67.20\%) compared to $122(32.80 \%)$ which were not legally registered by the concerned authority (Table 2). The respondent's self-evaluation as poor, middle class and rich and the extent of their dependency on the business they are running as a means of their livelihood and the number of they were accommodating was enquired, summarized and presented in Table 2.

As shown in the above table above, majority of the respondents classify themselves as middle income earners $139(37.40 \%)$ and the remaining 82(22\%) and $78(21 \%)$ consider themselves as rich and poor, respectively. In terms of dependency, about $208(55.90 \%)$ of the respondents depend on the business they are currently running as their livelihood while 184(44.10\%) have additional means to survive. Regarding employment size, about 245(65.90\%) of the respondents hire 1-5 employees including the manger/ the owner and family labor while $109(29.30 \%)$ of the respondents hired 6-10 employees. The remaining $10(2.70 \%)$ of the respondents hired $11-15$ workers.

\section{Table 2: Description of firm's characteristics.}

$\begin{array}{llll}\begin{array}{l}\text { Category/ } \\ \text { variable }\end{array} & \text { Characteristics } & \begin{array}{l}\text { Fre- } \\ \text { quency }\end{array} & \begin{array}{l}\text { Per- } \\ \text { cent }\end{array} \\ \text { Status } & \text { Registered } & 250 & 67.20 \\ & \text { Unregistered } & 122 & 32.80 \\ \text { Business } & \text { Service } & 284 & 76.30 \\ \text { sector } & \text { Industry } & 88 & 23.70 \\ \text { Ownership } & \text { Proprietorships } & 65 & 17.50 \\ \text { types } & \text { PLC } & 87 & 23.40 \\ & \text { Partnerships } & 220 & 59.10 \\ \text { Self } & \text { Poor } & 78 & 21.00 \\ \text { evaluation } & \text { Lower Middle income earner } & 73 & 19.60 \\ & \text { Middle income earner } & 139 & 37.40 \\ & \text { Rich } & 82 & 22.00 \\ \text { Dependency } & \text { Dependent } & 208 & 55.90 \\ \text { on business } & \text { Not dependent } & 164 & 44.10 \\ \text { Employmente } & \text { Self-employment } & 8 & 2.20 \\ \text { size } & 1-5 & 245 & 65.90 \\ & 6-10 & 109 & 29.30 \\ & 11-15 & 10 & 2.70\end{array}$

Source: Survey result, 2020.

Information sources and subsequent perception about the pandemic

As shown in the (Table 3), the biggest source of information for the respondents for hearing about the pandemic was social media 140(37.50\%), followed by mass media $117(31.50 \%)$ and family members $75(20.20 \%)$. Health staff was the least source of information on the pandemic $40(10.80 \%)$ in the study area.

The estimated distribution of time period by the respondents in which the pandemic may lead to the close of their business if the current trend continues was computed at 120 (32.26\%) for the two to three months category, while the six months to one year 
category was computed at 107(28.76). The one month and less and three to six months category were computed at 50(13.44\%) and 95(25.54), respectively. However, this would depend on the restriction set by the government and the local and global condition of the pandemic. The current glaring truth of the situations of SMEs in the study area was that all of them were experiencing decline in their business activities at a faster rate.

Table 3: Awareness of respondents about the pandemic outbreak.

$\begin{array}{llll}\text { Variable } & \text { Sources } & \text { Frequency } & \text { Percent } \\ \text { Information } & \text { Family members } & 75 & 20.20 \\ \text { Sources } & \text { Social media } & 140 & 37.50 \\ & \text { Health staff } & 40 & 10.80 \\ & \text { Mass media } & 117 & 31.50 \\ \text { Estimated } & \text { One month or less than } & 50 & 13.44 \\ \text { close down } & \text { Two to three months } & 120 & 32.26 \\ \text { Time-period } & \text { Three to six months } & 95 & 25.54 \\ & \text { Six months to one year } & 107 & 28.76\end{array}$

Source: Survey result, 2020.

Table 4: Major reasons for the disruption of the business and consequences.

\begin{tabular}{llllll}
$\begin{array}{l}\text { Disruptions } \\
\text { Reason for } \\
\text { disruption }\end{array}$ & $\begin{array}{l}\text { Fre- } \\
\text { quency }\end{array}$ & $\begin{array}{l}\text { Per- } \\
\text { cent }\end{array}$ & $\begin{array}{l}\text { Monthly } \\
\text { average total } \\
\text { revenues }\end{array}$ & $\begin{array}{l}\text { Fre- } \\
\text { quency }\end{array}$ & $\begin{array}{l}\text { Per- } \\
\text { cent }\end{array}$ \\
$\begin{array}{l}\text { Decrease in } \\
\text { demand }\end{array}$ & 114 & 30.60 & $0-25$ & 88 & 23.70 \\
$\begin{array}{l}\text { Movement } \\
\text { restrictions }\end{array}$ & 134 & 36.00 & $26-50$ & 147 & 39.50 \\
$\begin{array}{l}\text { Unavailability } \\
\text { of inputs }\end{array}$ & 124 & 33.30 & $51-100$ & 137 & 36.80 \\
\hline
\end{tabular}

Source: Survey result, 2020.

Effects and consequences of the pandemic on the respondents business

The great majority of the respondents report that their business was affected by various factors like decrease in demand for their products and services 114(30.60\%), movement restrictions and lockdowns $134(36 \%)$ and unavailability of inputs124 (33.30\%) (Table 4).

\section{Multiple problems faced by the respondents}

The critical problems the respondents faced as the result of COVID-19 is many and varied. In addition to the problems stated earlier, there are multiple problems affected each business as shown in Table 5.

Table 5: Multiple problems faced by respondents.

\begin{tabular}{|c|c|c|c|c|}
\hline \multirow[t]{2}{*}{ Types of Problems } & \multicolumn{2}{|l|}{ Yes } & \multicolumn{2}{|l|}{ No } \\
\hline & $\begin{array}{l}\text { Fre- } \\
\text { quency }\end{array}$ & $\begin{array}{l}\text { Per- } \\
\text { cent }\end{array}$ & $\begin{array}{l}\text { Fre- } \\
\text { quency }\end{array}$ & $\begin{array}{l}\text { Per- } \\
\text { cent }\end{array}$ \\
\hline Shortage of raw materials & 310 & 83.30 & 62 & 16.70 \\
\hline Transporting finished goods & 326 & 87.60 & 46 & 12.40 \\
\hline $\begin{array}{l}\text { shortage of cash inflows from } \\
\text { sales and loan }\end{array}$ & 348 & 93.50 & 24 & 6.50 \\
\hline Shortage of workers & 360 & 96.80 & 12 & 3.20 \\
\hline Increase in cost of production & 372 & 100.00 & - & - \\
\hline
\end{tabular}

Source: Survey result, 2020.

As shown in the Table 5, more than $80 \%$ of the respondents face multiple problems as the result of the outbreak of the pandemic and things like shortage of workers 360(96.80\%) and shortage of cash flow from sales and loan sources 348(93.50\%) being critical. The increase in cost of production affected the whole sample population of the survey and hence need serious approaches to tackle the problem as increase in cost of production affects the healthy operation of the business.

\section{Conclusions and Recommendations}

Overall, our paper contributes to assessing the economic impacts of COVID-19 on micro and small enterprises in Ethiopia. Multistage sampling techniques were selected to have a total of 372 respondents. Both descriptive statistics were used for this study as the method of data analysis. Our results provide due to the COVID-19 outbreak and restrictions to shut down the business, the SMEs have been extremely affected. In addition, those firms that have very low cash reserves are vulnerable and may not survive during the ongoing outbreak of COVID-19. Therefore, this study recommends that policy instruments have been introduced by the government in a coordinated way, to support Small and micro enterprises effectiveness of interventions until the economy recovers in Ethiopia.

\section{Novelty Statement}

In Ethiopia, more than $80 \%$ of the respondents face multiple problems as the result of the outbreak of the pandemic and things like shortage of workers $360(96.80 \%)$ and shortage of cash flow from sales 
and loan sources 348(93.50\%) being critical due to COVID-19 on micro and small enterprises

\section{Author's Contribution}

Milkessa Wakjira, Fikiru Temesgen, Chala Hailu and Dabesa Wegari jointly design the research article, administered the questionnaire, code, analyze data, interpret research results, and jointly write research report.

\section{Conflict of interest}

The authors have declared no conflict of interest.

\section{Reference}

IFC, 2020. International finance corporation. Helping small businesses navigate through COVID-19. March 20, 2020. https://www. uneca.org/.../insights-african-businesses'reactions-and-outlook- covid-19

ILO, 2020. International labor organization. Addressing the impacts of COVID-19 and Enterprises Briefing Note. May 21, 2020. https://www.ilo.org/empent/units/boosting... enterprise...en/index.htm

Worldometer, 2020. COVID-19 Coronavirus Pandemic, 2020 Available at: https://www. worldometers.info/coronavirus/ Accessed on: 2020 March 29 